\title{
PENERAPAN BAHAN AJAR MATEMATIKA BERBASIS RME TERHADAP KEMAMPUAN PENALARAN MATEMATIS SISWA
}

\author{
${ }^{1}$ Shelly Agustiani \\ ${ }^{1}$ Pendidikan Matematika, Fakultas Keguruan dan Ilmu Pendidikan, Universitas Muhammadiyah \\ Sukabumi \\ agustianishelly@gmail.com
}

\begin{abstract}
Abstrak
Tujuan penelitian ini adalah untuk mengetahui penggunaan bahan ajar matematika berbasis Realistic Mathemathics Education (RME) terhadap kemampuan penalaran matematis siswa. Metode penelitian yang digunakan dalam penelitian ini adalah metode kualitatif dengan jenis penelitian studi kepustakaan. Dari hasil penelitian dapat disimpulkan bahwa penggunaan bahan ajar matematika berbasis RME diharapkan dapat memberikan pengaruh terhadap kemampuan penalaran matematis siswa khususnya pada subbab Faktorisasi aljabar hal ini disebabkan karena dalam bahan ajar tersebut (1) Siswa diberikan permasalahan matematika yang berkaitan dengan kehidupan sehari-hari atau nyata sehingga diharapkan akan membuat siswa termotivasi. (2) Pada bahan ajar tersebut terdapat indikator kemampuan penalaran matematis siswa yang diharapkan dapat melatih dan memberikan pengaruh terhadap kemampuan penalaran matematis siswa (3) Keterlibatan dan minat siswa akan meningkat karena menggunakan permasalahan yang ada dilingkungan mereka. (4) Pada bahan ajar tersebut terdapat prinsip dan karakteristik RME yang diharapkan dapat meningkatkan minat, motivasi, dan keterlibatan siswa dalam proses kegiatan pembelajaran.
\end{abstract}

Kata Kunci: RME, bahan ajar matematika berbasis RME, Kemampuan penalaran matematis.

\section{PENDAHULUAN}

Perkembangan ilmu pengetahuan dan teknologi berkembang sangat pesat di era sekarang hal tersebut harus juga diiringi dengan adanya sumber daya manusia yang berkualitas. Sumber daya manusia yang berkualitas ini dapat diperoleh melalui beberapa indikator salah satunya yaitu melalui pendidikan. Dalam pendidikan salah satu mata pelajaran yang sangat bermanfaat dan berguna dalam kehidupan sehari-hari adalah matematika.

Mullis et al.(2012) menjelaskan bahwa "Students need to develop mathematical understanding to manage successfully in school and society". Mempelajari matematika sangat penting karena tidak hanya berguna untuk kesuksesan siswa dilingkungan sekolah saja tetapi dilingkungan masyarakat juga. Oleh karena itu, guna memenuhi tuntutan era saat ini dimana perkembangan teknologi dan ilmu pengetahuan menjadi salahsatu indikator berkembangnya suatu bangsa maka pembelajaran matematika perlu dilakukan sejak usia dini.

Desoete (2009) menjelaskan bahwa It is hard not to overemphasize the importance of mathematical literacy in our society. In everyday life situations we need to be in time, pay bills, follow directions or use maps, look at bus or train timetables or comprehend instruction leaflets and expiry dates. A lack of mathematical literacy was found to affect people's ability to gain full- 
time employment and often restricted employment options to manual and often low paying job. Mempelajari matematika sangat penting tetapi masih banyak siswa atau masyarakat yang belum melek terhadap matematika. Menekankan pentingnya mempelajari matematika sangat sulit di masyarakat. Padahal matematika sangat berguna dalam kehidupan sehari-hari seperti ketika melihat jam untuk menentukan waktu, ketika melakukan transaksi pembayaran, menentukan takaran dalam memasak atau meminum obat dan masih banyak lagi. Melihat begitu pentingnya matematika, di era saat ini kurangnya mempelajari matematika dapat juga menyebabkan seseorang kesulitan bersaing salahsatunya dalam hal mendapatkan pekerjaan yang layak.

Matematika merupakan salah satu mata pelajaran yang diajarkan hampir disemua tingkat pendidikan mulai dari tingkat sekolah dasar hingga perguruan tinggi. NCTM (Harahap, 2018) menyatakan bahwa 5 keterampilan proses yang perlu dimiliki siswa yaitu: (1) pemecahan masalah (Problem Solving); (2) Penalaran dan pembuktian (Reasoning and Proof); (3) Komunikasi (Communication); (4) Koneksi (Connection); (5) Representasi (Representation). Setelah mempelajari matematika diharapkan siswa mempunyai 5 keterampilan tersebut. Mempunyai Keterampilan-keterampilan tersebut diharapkan dapat membantu siswa dalam memahami konsep matematika yang dapat digunakan untuk menyelesaikan permasalahan-permasalahan matematika.

Diantara 5 keterampilan tersebut, kemampuan penalaran matematis merupakan salah satu kemampuan matematika yang perlu untuk dikuasai oleh siswa. Hartono (2014) menyatakan bahwa penalaran merupakan proses menyeleksi dan menganalisa suatu informasi yang diterima hingga sampai pada kesimpulan yang sah berdasarkan data-data yang ada. Suherman dan Winataputra (Sumartini, 2015) mengatakan bahwa "Penalaran adalah proses berfikir yang dilakukan dengan suatu cara untuk menarik kesimpulan". Berdasarkan pendapat para ahli tersebut, penulis mengambil kesimpulan bahwa penalaran adalah proses berpikir yang dilakukan untuk menarik kesimpulan berdasarkan data dan fakta yang relevan.

Penalaran matematis memiliki pengertian yang berbeda-beda seperti yang dikemukakan oleh beberapa ahli berikut ini. Kusumah (Lestari dkk, 2016) menyatakan bahwa, "Kemampuan penalaran matematis adalah kemampuan memahami pola hubungan di antara dua objek atau lebih berdasarkan aturan, teorema, atau dalil yang telah terbukti kebenarannya". Berdasarkan pendapat para ahli diatas, penulis mengambil kesimpulan bahwa penalaran matematis adalah suatu proses berpikir memahami pola atau konsep matematika untuk mengambil kesimpulan yang disertai bukti dan alasan yang logis

Kemampuan penalaran matematis erat kaitannya dengan pembelajaran matematika. Kemampuan penalaran seseorang dapat mempengaruhi baik tidaknya seseorang dalam mempelajari ilmu matematika. Depdiknas menyatakan bahwa materi matematika dan penalaran matematis dua hal yang sangat terkait dan tidak dapat dipisahkan, karena materi matematika dipahami melalui penalaran dan penalaran dipahami dan dilatihkan melalui belajar matematika (Mikrayanti, 2016).

Di Indonesia, sebagian besar siswa memiliki kemampuan penalaran matematis yang tergolong rendah. Hal tersebut berdasarkan dari laporan hasil survey The Trends in International Mathematics and Science Study (TIMSS) dan Programme for International Student Assesment (PISA) yang menunjukkan rendahnya nilai rata-rata matematis dari peserta didik Indonesia. Pada tahun 2015 hasil survey PISA menunjukkan Indonesia berada pada peringkat 63 dari 70 negara (OECD, 2016) dan berdasarkan hasil studi TIMSS tahun 2015 indonesia berada 
pada peringkat 44 dari 49 negara(IEA, 2016). Berdasarkan hal tersebut dapat disimpulkan bahwa kemampuan penalaran matematis di Indonesia tergolong rendah.

Dalam kegiatan pembelajaran matematis tinggi rendahnya kemampuan penalaran matematis siswa dapat dilihat salahsatunya melalui beberapa indikator. Sumarto (Sumartini, 2015) menyatakan bahwa indikator kemampuan penalaran matematis dalam pembelajaran matematis adalah (1) menarik kesimpulan, (2) memberikan penjelasan dengan model, fakta, sifat-sifat dan hubugan, (3) memperkirakan jawaban dan proses solusi, (4) Menggunakan pola dan hubungan untuk menganalisis situasi matematis, (5) Menyusun dan mengakaji konjektur, (6) Merumuskan lawan mengikuti aturan inferensi, memeriksa validant argument, (7) Menyusun argument-argumen yang valid, (8) Menyusun pembuktian langsung, tak langsung, dan menggunakan induksi matematis.

Berdasarkan pendapat para ahli tersebut, terdapat beberapa indikator yang digunakan oleh penulis untuk mengukur kemampuan penaralan matematis siswa. Indikator yang dirasa paling tepat dan sesuai dengan penelitan ini yaitu (1) mengajukan dugaan, (2) Melakukan manipulasi matematika, (3) Menyusun kesimpulan dengan memberikan bukti dan alasan terhadap kesimpulan tersebut

Banyak faktor yang mungkin menjadi penyebab rendahnya kemampuan penalaran matematis siswa salah satunya yaitu rendahnya minat siswa dalam belajar matematika, kurangnya motivasi siswa untuk belajar, kurangnya perhatian siswa terhadap pelajaran matematika ketika guru menjelaskan, penggunaan model pembelajaran yang kurang bervariasi dan kurangnya keaktifan siswa dalam proses pembelajaran. Hal tersebut dapat terjadi dikarenakan terdapat beberapa guru yang masih mengalami kesulitan dalam mengembangkan kegiatan pembelajaran yang dapat meningkatkan kemampuan penalaran matematis siswa. Hal tersebut juga sejalan dengan ketersedian bahan ajar yang berbasis kemampuan penalaran matematis siswa yang masih kurang.

Dalam kegiatan pembelajaran, bahan ajar merupakan salah satu hal yang harus diperhatikan. Melihat pentingnya bahan ajar maka pemilihan dan penggunaan bahan ajar harus sesuai dan tepat dengan keadaan siswa. Pemilihan dan penggunaan bahan ajar yang tepat dapat membantu guru maupun siswa dalam mencapai tujuan dari pembelajaran tersebut. Oleh karena itu diperlukan bahan ajar yang sesuai yang dapat meningkatkan keterlibatan siswa dalam kegiatan pembelajaran dan juga dapat meningkatkan kemampuan penalaran matematis siswa. Bahan ajar tersebut lebih baik jika mengaitkan pembelajaran dengan hal-hal yang nyata atau konkret. Hal tersebut dapat memberikan kesempatan kepada siswa agar dapat mengkontruksi dan menghasilkan konsep matematika dengan cara dan bahasa mereka sendiri dengan dibimbing oleh guru sehingga dapat meningkatkan minat dan motivasi siswa dalam belajar matematika. Salah satu bahan ajar yang mengaitkan pembelajaran dengan hal-hal yang nyata atau konkret yaitu bahan ajar berbasis Realistic Mathematic Education (RME).

Terdapat beberapa penelitian yang mengatakan bahwa penggunaan pendekatan atau bahan ajar RME dapat meningkatkan kemampuan penalaran matematis siswa. Salah satunya yaitu Hasil penelitian yang dilakukan oleh Nur Amaliyah (2018) menyatakan bahwa "Terdapat efektivitas yang signifikan antara penggunaan pendekatan RME (Realistic Mathematic Education) terhadap kemampuan penalaran matematis siswa di kelas. Dengan kata lain kemampuan penalaran matematis siswa menjadi lebih baik setelah menggunakan pendekatan RME. Hal tersebut sejalan dengan Hasil penelitian yang dilakukan oleh Arif, dkk (2016) menyatakan bahwa LKS 
dapat meningkatkan kemampuan penalaran matematis siswa, memperdalam pemahaman siswa dan memiliki tampilan yang menarik. LKS tersebut dapat memfasilitasi kurikulum KTSP dan kurikulum 2013. Oleh karena itu bahan ajar yang digunakan oleh guru harus memuat konsep matematika dalam kehidupan sehari-hari, menarik minta siswa dan memotivasi siswa.

Suatu bahan ajar disebut sebagai bahan ajar berbasis RME jika memuat prinsip dan karakteristik RME. Freudenthal dalam Gravemeijer (1994) menyatakan bahwa dalam pembelajaran RME terdapat tiga prinsip yang dapat dijadikan sebagai acuan penelitian untuk instructional design yaitu: (1) guided reinvention and progressive mathematizatio, (2) didactical phenomenology dan (3) self-developed models. Terdapat lima karakteristik "five tenets" RME menurut (Treffers, 1987; Bakker, 2004): yaitu : (1). Phenomenological exploration. (2) Using models and symbols for progressive mathematization. (3) Using students' own construction and productions.(4). Interactivity dan (5). Intertwinement.

Dalam kaitan pentingnya permasalahan di atas, maka penulis merasa perlu diterapkan pembelajaran matematika yang menggunakan bahan ajar matematika berbasis RME yang diharapkan dapat memberikan pengaruh terhadap kemampuan penalaran matematis siswa. Tujuan dari penelitian ini adalah untuk mengetahui bagaimana efektifitas penerapan bahan ajar matematika berbasis RME terhadap kemampuan penalaran matematis siswa.

\section{METODE}

Metode penelitian yang digunakan dalam penelitian ini adalah metode kualitatif dengan jenis penelitian studi kepustakaan. Penelitian studi kepustakaan merupakan suatu jenis penelitian yang digunakan dalam pengumpulan informasi dan data secara mendalam melalui berbagai literatur, buku, catatan, serta hasil penelitian sebelumnya yang relevan, untuk mendapatkan jawaban dan landasan teori mengenai masalah yang akan diteliti.

\section{HASIL DAN PEMBAHASAN}

Menurut Depdiknas (2006b:1), bahan ajar adalah segala bentuk bahan yang digunakan guru/instruktur dalam melaksanakan kegiatan belajar mengajar. Bahan ajar matematika berbasis RME merupakan sekumpulan materi dan soal matematika yang memuat prinsip dan karakteristik RME. Dalam bahan ajar ini permasalahannya dikaitkan dengan lingkungan atau pengalaman siswa yang nyata (realistic) agar dapat dibayangkan oleh siswa. Hal tersebut bertujuan agar dapat membantu siswa mengindentifikasi dan memahami konsep dasar matematika.

Materi yang terdapat pada bahan ajar berbasis RME ini yaitu materi aljabar subab faktorisasi aljabar. Materi aljabar biasa diajarkan kepada siswa SMP. Dalam pembelajaran materi aljabar masih terdapat beberapa siswa yang mengalami kesulitan dalam memahami materi aljabar. Hal tersebut dikarenakan materi aljabar kebanyakan berisi materi yang abstrak, hal tersebut membuat sebagian siswa mengalami kesulitan dalam memahami materi aljabar tersebut. Karena matematika merupakan ilmu yang terstruktur dimana satu materi berkaitan dengan materi yang lain. Maka dibuatlah bahan ajar berbasis RME ini pada materi aljabar khususnya materi faktorisasi aljabar. Dengan bahan ajar ini diharapkan dapat membantu siswa dalam proses kegiatan pembelajaran dan memberikan pengaruh terhadap kemampuan penalaran matematis siswa.

Dalam bahan ajar berbasis RME ini mengaitkan materi aljabar dengan kehidupan sehari-hari, sehingga siswa dapat menemukan konsep dengan cara dan menggunakan bahasanya sendiri dengan dimbing oleh guru. Sehingga menjadikan 
siswa turut serta berperan aktif dalam kegiatan pembelajaran dan dapat meningkatkan minat dan motivasi siswa .(Student contribution, interactivity, Karakteristik RME); (Guided Reinvention, Didactical Phenomology, self developed models ).

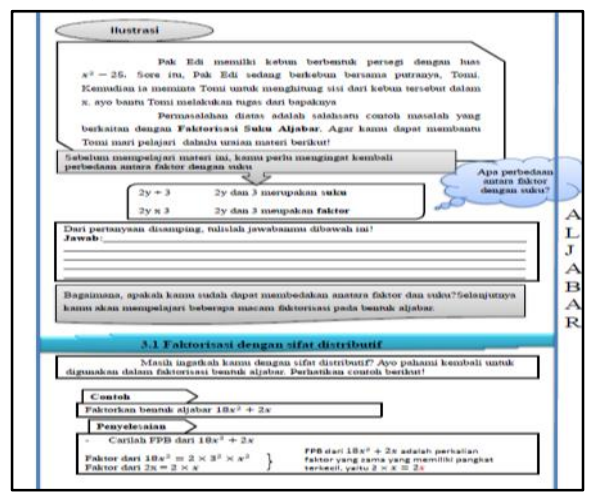

Gambar Layout 1

Dari gambar diatas dapat dilihat bahwa dalam bahan ajar matematika berbasis RME ini, sebelum siswa diajarkan mengenai materi baru atau faktorisasi aljabar siswa diingatkan kembali dengan materi sebelumnya yang sudah dipelajari oleh siswa yang ada kaitannya dengan materi faktorisasi aljabar yaitu materi faktor dan suku. Siswa diberikan sebuah permasalahan yang nyata atau konstektual. Pada gambar diatas terdapat pertanyaan mengenai faktor dan suku dengan menggunakan permasalahan yang nyata atau konstektual (Prinsip RME, didactical phenomenology). Hal tersebut dilakukan untuk menyamakan konsep dan membantu siswa dalam mempelajari materi Faktorisasi aljabar. Dengan adanya kaitan antara pembelajaran matematika dengan kehidupan sehari-hari maka akan membuat siswa dapat melihat kegunaan dari mempelajari matematika terhadap kehidupan sehari-hari sehingga siswa lebih termotivasi dan berminat dalam mempelajari matematika.

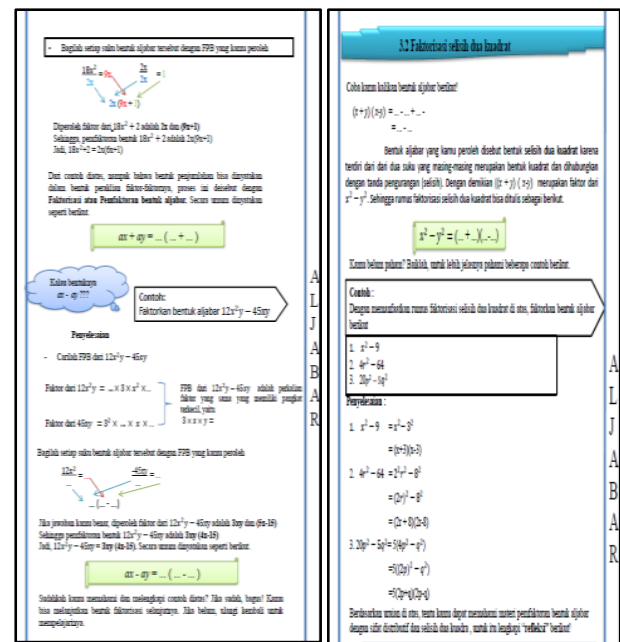

Gambar Layout 2

Dalam pembelajaran dengan bahan ajar ini, setelah siswa diberikan suatu permasalahan yang nyata atau ada dikehidupan sehari-hari mengenai faktorisasi aljabar. Kemudian siswa diberikan sebuah permasalahan dari situasi real ke situasi yang abstrak. Hal tersebut diharapkan dapat memberikan pengaruh terhadap kemampuan penalaran matematis siswa. Hal tersebut dilakukan agar siswa dapat menggeneralisasikan hasil pemikirannya kedalam bahasa matematika. Contoh yang disajikan dalam bahan ajar ini menggunakan anak panah yang berwana-warni dengan tujuan agar siswa dapat lebih mudah mempelajarinya dan dapat menarik minat siswa. Setelah mempelajari materi kemudian aktivitas siswa yaitu siswa dilatih membuat kesimpulan dari materi yang telah dipelajari tersebut dengan menyebutkan dan membuktikan kebenaran dari argument tersebut (indikator penalaran). Hal tersebut dapat membuat siswa mengerti dan memungkinkan materi yang diajarkan lebih lama untuk diingat oleh siswa, karena yang diajarkan siswa disini menemukan konsep dari materi aljabar tersebut dengan menggunakan bahasanya sendiri dengan dibimbing oleh guru.

Setelah menyimpulkan materi yang telah dipelajari aktifitas siswa selanjutnya yaitu siswa diberi sebuah permasalahan. Dimana permasalahan tersebut berbeda dari 
contoh yang sudah diberikan dan dipelajari oleh siswa. Hal tersebut dilakukan untuk meningkatkan pemahaman siswa terhadap materi tersebut. Agar siswa tidak hanya mengerti materi tersebut tetapi siswa paham mengenai konsep dari materi tersebut, sehingga jika siswa diberikan sebuah permasalah yang berbeda dari yang sudah dipelajari, siswa tetap dapat menyelesaikan permasalahan tersebut. Karena siswa memahami konsep dari materi tersebut.

Selanjutnya aktivitas siswa yaitu mengajukan dugaan dan melakukan manipulasi matematika dengan mengikuti petunjuk yang ada dalam bahan ajar tersebut. Siswa memberikan dugaan jawaban terhadap pertanyaan yang terdapat pada bahan ajar tersebut dengan cara mengisi titik-titik yang ada pada bahan ajar tersebut. Kemudian siswa melakukan manipulasi matematika sesuai dengan permasalah yang diberikan tersebut. Kemudian yang terakhir siswa menarik kesimpulan dengan cara siswa menuliskan rumus atau konsep dari materi tersebut berdasarkan jawaban yang yang diperoleh dengan menyertakan alasan dan bukti dari kesimpulan tersebut. Hal tersebut sesuai dengan indikator penalaran matematis yang dipilih oleh penulis. Hal tersebut diharapkan dapat melatih kemampuan penalaran matematis siswa.

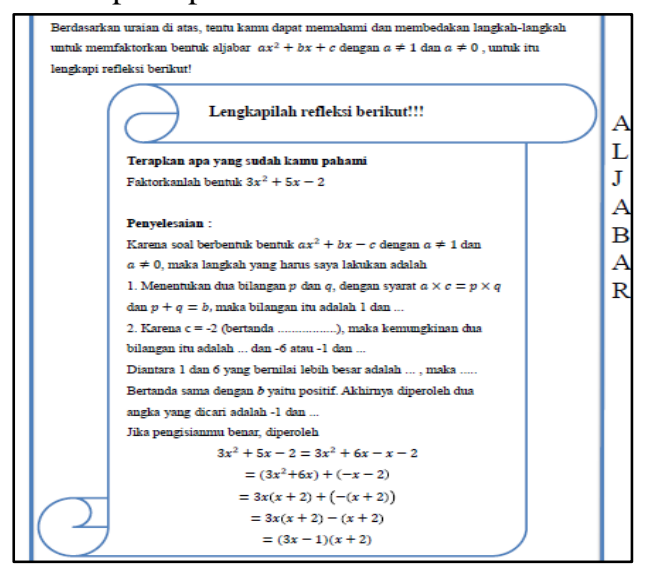

Gambar Layout 3

Dalam bahan ajar ini juga terdapat kolom atau bagian refleksi yang berisi langkah-langkah untuk menyelesaikan pemfaktoran bentuk aljabar hal tersebut dilakukan untuk menerapkan apa yang telah dipelajari oleh siswa. Agar siswa lebih paham mengenai materi yang telah dipelajari. Dalam bahan ajar ini siswa dituntut untuk menemukan dan mengkonstruksikan pengetahuannya. Dengan cara mengisi titik-titik yang ada pada bagian refleksi berdasarkan apa yang telah dipelajari oleh siswa. Pada bagian tersebut terdapat indikator penalaran matematis. Yang pertama siswa mengajukan dugaan terhadap permasalahan yang diberikan. Selanjutkan siswa melakukan manipulasi matematika terhadap permasalahan yang diberikan tersebut dengan berpacu atau melihat kepada contohcontoh yang telah diberikan sebelumnya. Yang terakhir siswa menyusun kesimpulan dengan memberikan bukti dan alasan terhadap kesimpulan tersebut. Dalam bahan ajar ini juga terdapat kunci jawaban yang ada dibawah soal, yang dapat digunakan oleh siswa untuk memeriksa kebenaran jawaban yang diperolehnya. Oleh karena itu penggunaan bahan ajar berbasis RME ini diharapkan dapat melatih kemampuan penalaran matematis siswa.

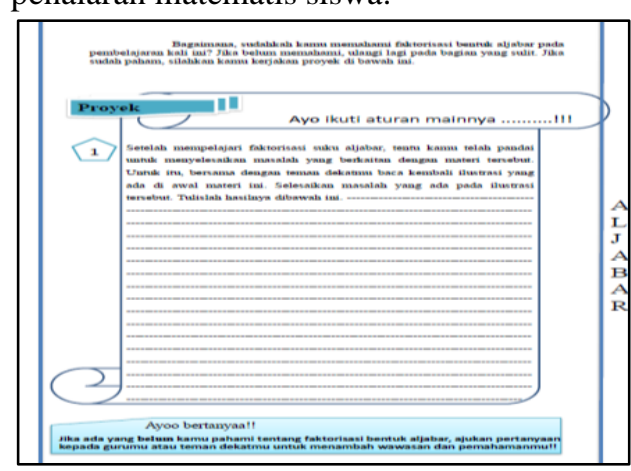

Gambar Layout 4 (Tugas Proyek)

Setelah siswa selesai mempelajari mengenai materi faktorisasi aljabar, kemudian siswa dilatih untuk menyelesaikan permasalahan yang berkaitan dengan kehidupan nyata mengenai faktorisasi aljabar yang ada di awal materi berdasarkan yang telah dipelajari. Tugas proyek 1 tersebut dilakukan secara berkelompok sesuai dengan kelompok yang sudah dibagi oleh guru. Tugas proyek tersebut dapat 
melatih siswa membuat kesimpulan dari kegiatan pembelajaran yang telah dilakukan tadi dari awal sampai selesai dan juga melatih kerjasama antar siswa dimana menyatukan pendapat para siswa menjadi satu dan juga bisa membantu siswa yang kurang paham mengenai materi Faktorisasi Aljabar dengan dibantu oleh teman sekelompoknya. Dengan diberikannya tugas proyek tersebut diharapkan dapat menjadikan siswa lebih aktif dikelas, meningkatkan minat dan motivasi siswa dan mendorong rasa kerjasama antar siswa.

Setelah selesai mengerjakan tugas proyek, selanjutnya siswa mempresentasikan hasil dari pemikiran kelompoknya didepan kelas dengan diwakili oleh perwakilan kelompoknya. Selanjutnya guru memberikan pendapat dan membenarkan jawaban siswa jika dirasa masih ada jawaban yang kurang tepat. Hal tersebut dapat menjadikan siswa lebih aktif dalam proses pembelajaran.

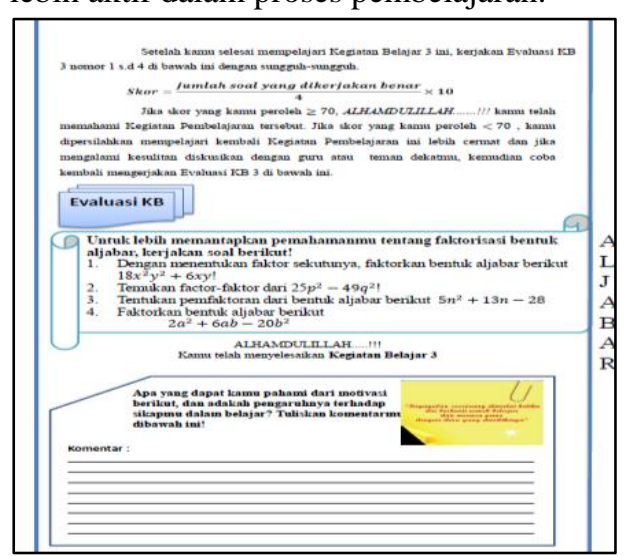

Gambar Lembar Aktivitas Siswa

Setelah tugas proyek, dalam bahan ajar ini terdapat evaluasi kegiatan belajar yang merupakan tugas individu siswa. Hal tersebut dilakukan untuk melatih pemahaman masing-masing siswa dan untuk mengukur kemampuan siswa mengenai Faktorisasi Aljabar.

Bahan ajar berbasis RME ini diharapkan dapat memberikan pengaruh positif terhadap kemampuan penalaran matematis siswa dikarenakan di dalam bahan ajar tersebut terdapat karakteristik dan prinsip RME dan juga terdapat indikator- indikator dari kemampuan penalaran matematis siswa.

\section{KESIMPULAN}

Berdasarkan hasil penelitian tersebut maka dapat disimpulkan bahwa penerapan bahan ajar matematika berbasis RME pada materi pelajaran Faktorisasi aljabar diharapkan dapat memberikan pengaruh positif terhadap kemampuan penalaran matematis siswa, hal ini disebabkan karena

1. Siswa diberikan permasalahan matematika yang berkaitan dengan kehidupan sehari-hari sehingga diharapkan membuat siswa termotivasi.

2. Pada bahan ajar tersebut terdapat indikator kemampuan penalaran matematis siswa, yang diharapkan dapat melatih kemampuan penlaran matematis siswa dan diharapkan dapat memberikan pengaruh terhadap kemampuan penalaran matematis siswa

3. Keterlibatan siswa dan minat siswa akan meningkat karena siswa diberikan permasalahan yang ada dilingkungan mereka.

4. Pada bahan ajar tersebut terdapat prinsip dan karakteristik RME yang diharapkan dapat meningkatkan minat, motivasi, dan keterlibatan siswa dalam proses kegiatan pembelajaran.

\section{DAFTAR PUSTAKA}

Afriansyah E. 2016. Makna Realistic dalam RME dan PMRI. Lemma Vol 11 No. 2, Mar 2016.

Amaliyah N. Harahap. 2018. Efektivitas Penggunaan Pendekatan Rme (Realistic Mathematic Education) Terhadap Kemampuan Penalaran Matematis Siswa Di Kelas XI SMA NEGERI 7 PADANGSIDIMPUAN.Jurnal MathEdu Vol.1 No. 2 http://journal.ipts.ac.id/index.php/MathE du/article/view/441. Diunduh $10 \mathrm{mei}$ $\underline{2020}$ 
Arif Hidayatul Khusna, Ipung Yuwono, Makbul Muksar. (2016). Pengembangan Lembar Kerja Siswa (LKS) Berkarakteristik Rme Materi Barisan dan Deret Untuk Kelas X. Jurnal Pendidikan: Teori, Penelitian, dan Pengembangan Vol. 1 No. 4. Diunduh tanggal 10 mei 2020.

http://journal.um.ac.id/index.php/jptpp/ar $\underline{\text { ticle/view/6242 }}$

Depdiknas. 2006b. Pedoman memilih dan menyusun bahan ajar. Jakarta: Depdiknas.

Desoete, A. 2009. Mathematics and metacognition in adolescents and adults with learning disabilities. International Electronic Journal of Elementary Education Vol. 2. No 1. Hal 83

Harahap, Muhammad Syahril. 2018. Meningkatkan Kemampuan Pemecahan Masalah Dengan Penggunaan Bahan Ajar RME. ISSN: 2527-4295

Hartono Yusuf. (2014). Matematika Strategi Pemecahan Masalah. Yogyakarta: Graha Ilmu.

IEA. (2016). TIMSS 2015 International Result in Mathematics. http://timss2015.org/wpcontent/upload/fi lebase/full\%20pdfs/T15InternationalResult-in-MathematicsGrade-4.pdf.

Lestari, Indah, dkk. 2016.Peningkatan Kemampuan Penalaran Matematis Siswa Menggunakan Pendekatan Pendidikan Matematika Realistik.Jurnal Inovasi Pendidikan Dasar, 1(2), 1 - 8, 2016.

Mikrayanti. (2016). Meningkatkan Kemampuan Penalaran Matematis Melalui Pembelajaran Berbasis Masalah. Suska Journal of Mathematics Education, Vol. 2 No.2. Diunduh tanggal 10 Mei 2020, http://ejournal.uinsuska.ac.id/index.php/SJME/article/view/ $\underline{1547}$

Mullis, I.V.S., Martin, M. O., Foy, P., \& Arora, A. 2012. TIMSS 2011 International Results in Mathematics. Chestnut Hill: TIMSS \& PIRLS International Study Center. Tersedia di https://timssandpirls.bc.edu/timss2011/do
wnloads/T11_IR Mathematics_FullBook .pdf diunduh 10 mei 2020.

OECD. (2016). PISA 2015 Result in Focus. https://www.oecd.org/pisa/pisa-2015result-in-focus.pdf

Resa Elvira. 2015. Modul Matematika Aljabar. FKIP Universitas Muhammadiyah Ponorogo, 2015. Diakses 30 maret 2020.

Sumartini, Tina Sri. 2015. Peningkatan Kemampuan Penalaran Matematis Siswa Melalui Pembelajaran Berbasis Masalah. Jurnal Pendidikan Matematika, Volume 5, Nomor 1, April 2015. 